\title{
Root systems of two Patagonian shrubs: A quantitative description using a geometrical method
}

\section{ROBERT J. FERNÁNDEZ A. AND JOSE M. PARUELO}

\begin{abstract}
A method for mapping coarse root distribution suitable for stony solls was developed. Each root is considered as a broken line, whose segments are fairly straight root portions. The spatial location of end points of these segments is recorded in the field through 3 coordinates: its distance from plant vertical axis, its depth, and its distance to the foregoing point on the same root. With these data the roots' spatial arrangement is reproduced using a computer program including simple geometrical relationships. The main advantages of the method are: (a) it does not require sample harvesting and handling; (b) it considers root length instead of root biomass; and (c) its quantitative character allows statistically valid comparisons. Two species living in the Patagonian semidesert were studied: neneo (Mulinum spinosum, Umbeliferae) and mata mora (Senecio filaginoides, Compositae). In both shrubs, roots extend laterally more than $\mathbf{2} \mathrm{m}$ and root length decreases exponentially as the distance from the canopy edge increases. Neneo was found to have its maximal root density at a depth of $0.4 \mathrm{~m}$, whereas mata mora has most of its roots close to the soil surface. An interpretation of the differential response of these shrubs to graxing derives from these results.
\end{abstract}

Key Words: Mulinum spinosum, Senecio filaginoides, stony soil, Argentina

The paucity of knowledge of root systems relative to its importance is well known. In the case of plants growing in stony soils, as in the Patagonian arid steppe, the usual methodological difficulties are even greater. Previous studies of root systems in this environment referred to the root distribution of forbs (Golluscio and Sala 1985) and grasses (Soriano et al. 1987). For shrubs, only brief, qualitative descriptions have been reported (Soriano 1956, Soriano and Sala 1983).

\footnotetext{
Authors are graduate students at the Departamento de Ecologia, Facultad de Agronomia, Universidad de Buenos Aires. Av. San Martin 4453. (1417) Buenos Aires, Argentina.

This work was financially supported by a grant (PID 911902/85) from CONICET (Consejo Nacional de Investigaciones Cientificas y Técnicas, Argentina) and field facilities were provided by INIA (Instituto Nacional de Tecbnologia Agropecuaria), During part of the time devoted to this work, a fellowship was granted to RJFA by the Fundación Bunge y Born.

V. Sadras, E. Montecinos U., S.E.B. Hall and Professor A. Soriano offered valuable suggestions at different stages of the preparation $f$ the manuscript. The statistical software used was developed by P.J. Aphalo and R.A. Golluscio.

Manuscript accepted 28 January 1988.
}

Our objective was to quantify the spatial distribution of roots of 2 woody species: neneo (Mulinum spinosum, Umbeliferae) and mata mora (Senecio filaginoides, Compositae). These species account for $76 \%$ of the woody cover and $19 \%$ of the total cover in the west, central Patagonia (R.A. Golluscio, unpublished data), with an estimated density of 1,200 and 1,900 plants/ha respectively (Fernández A. 1986).

To achieve this objective, it was necessary to develop a reliable method suited to the high stone content of the soil. At the same time, the procedure should not need excessive work, in order to allow replication and statistical inference.

\section{Site Description}

The study was carried out near the town of Rio Mayo $\left(45^{\circ} 25^{\prime} \mathrm{S}\right.$ Lat., $70^{\circ} 20^{\circ} \mathrm{W}$ Long., $500 \mathrm{~m}$, Province of Chubut, Argentina) in a stand representative of the community of coiron amargo (Stipa speciosa and $S$. humilis), mamuel choique (Adesmia campestris), calafate (Berberis heterophylla), and pasto hilo (Poa lanuginosa) (Golluscio et al. 1982) which is present on plateaus.

This arid steppe is dominated by 3 shrubs (neneo, mata mora and mamuel choique) and by several tussock grasses (coirón amargo and coirón poa $=$ Poa ligularis). Sheep graze year round on this type of vegetation, except for the summer months on farms with coiron blanco (Festuca pallescens) grasslands or wet valleys ("mallines").

Mean annual temperature is $7,8^{\circ} \mathrm{C}\left(\mathrm{July}: 2^{\circ} \mathrm{C}\right.$; January: $\left.14^{\circ} \mathrm{C}\right)$ Average precipitation is $142 \mathrm{~mm}$ per year, $64 \%$ of which falls during the coldest season of April to September. Strong west winds blow during the whole year. The soil is a Calciorthid (Golluscio et al. 1982). Gravel (>5 mm) accounts for $47 \%$ of its total weight. More detailed information about the environment and the 2 shrubs studied can be found in Soriano (1983) and Soriano and Sala (1983).

\section{Materials and Methods}

The variable considered in the development of this method was root length, which is judged to be a better index of root ability for water and nutrient uptake than root biomass (Bóhm 1979). The method used is of a geometrical character. Each root and each ramification is considered as a broken line, whose segments are 
fairly straight root portions.

For each shrub species, 5 plants of modal size (A.H. Nuñez, pers. comm.) were sampled (Table 1). These individuals are encircled by a ring of tussock grasses (Soriano 1981). The distance between sampled shrubs and the nearest neighbor was not less than $1 \mathrm{~m}$.

Table 1. Size range of the 5 shrubs measured for each species.

\begin{tabular}{ccc}
\hline & Neneo & Mata mora \\
\hline $\begin{array}{c}\text { MD } \\
(\mathrm{cm})\end{array}$ & $112-136$ & $70-100$ \\
$\begin{array}{c}\mathrm{md} \\
(\mathrm{cm})\end{array}$ & $74-120$ & $57-78$ \\
$\mathrm{H}$ & $58-68$ & $44-52$ \\
$(\mathrm{~cm})$ & & \\
\hline
\end{tabular}

MD: maximum diameter; md: minimum diameter; $\mathrm{H}$ : height.

At the side of each plant a trench was dug in such a way that 2 of its walls joined with a $90^{\circ}$ solid angle at the vertical axis of the plant. With origin in one of these walls, and with vertex in the center of the plant, $a 4^{\circ}$ horizontal angle was traced on the surface of the soil, defining an eighth of a cylinder around the plant, which was considered the sampling unit (Fig. 1).

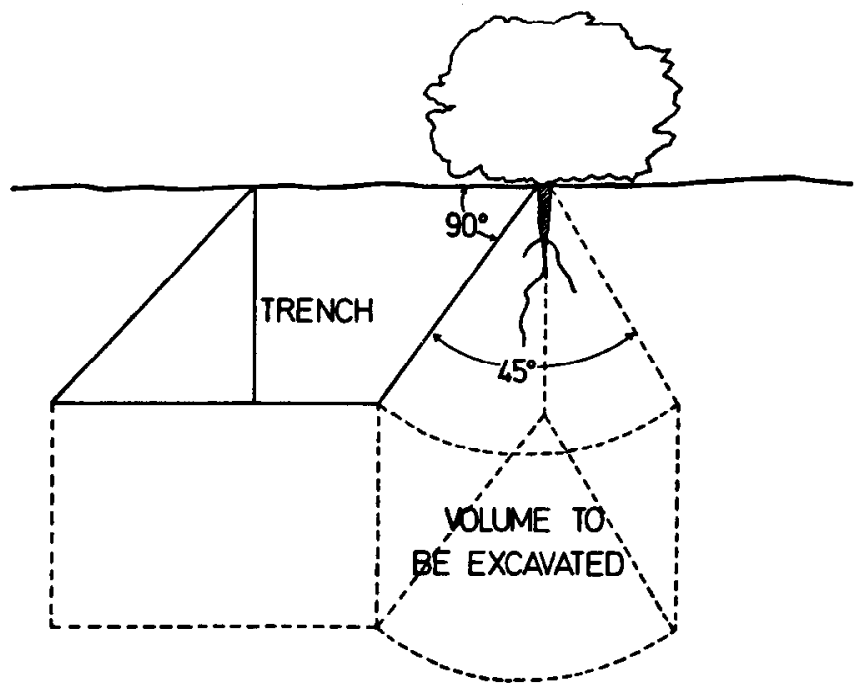

Fig. 1. Scheme of a sampling unit before root exposure.

With careful soil removal, the roots were exposed, and the spatial location of end points $(Q)$ of each approximately straight root segment was recorded through 3 coordinates: its distance to the central axis of the shrub (DIST (Q)), its depth (DEPTH (Q)), and it distance to the foregoing point on the same root (LENGTH $(P, Q))$.

From these data, it was possible to rebuild the 2 dimensional arrangement of roots through a 3-step algorithm (included in a BASIC computer program available from the authors):

a) Calculation of the length of each segment corresponding to each depth interval (VL(i)) (Fig. 2).

b) Calculation of the length of segment included in each horizontal distance interval (HL(j)) (Fig. 3).

c) Combination of the foregoing steps in such a way that the vertical and horizontal position of the segment is obtained. In other words, calculation of the length of the segment RL (i,j) located in each cell $(\mathrm{i}, \mathrm{j})$ of a $10 \mathrm{~cm} \times 10 \mathrm{~cm}$ grid, re-building the 2 dimensional arrangement of the roots. (The horizontal origin of the pair of coordinates used as a reference is located at the center of the plant, and the vertical origin at the soil surface level.) This third step was considered necessary to avoid losing the interactions

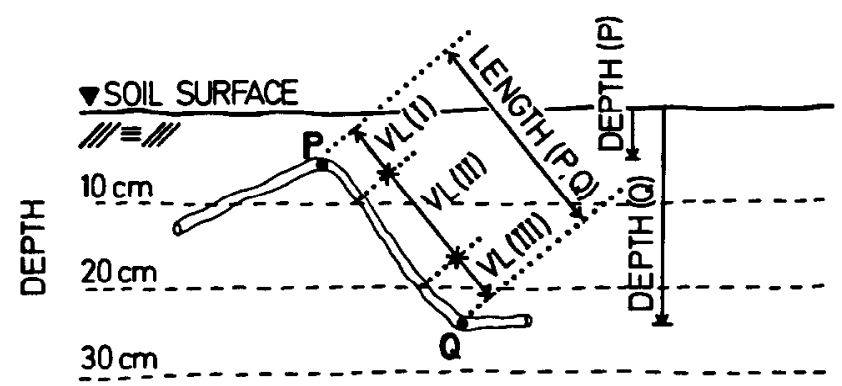

Fig. 2. Model used to estimate vertical distribution of roots. $P$ and $Q$ : points of a root between which it can be considered a straight segment. Data: DEPTH(P), DEPTH(Q) and LENGTH $(P, Q)$.

Unknowns: length of segment $P Q$ included in each stratum (VL(i)). Solution:

$V L(I)=10-D E P T H(P) * L E N G T H(P, Q) /(D E P T H(Q)-D E P T H(P))$

$V L(I I)=20-10 * \operatorname{LENGTH}(P, Q) /(D E P T H(Q) D E P T H(P))$

$V L(I I I)=D E P T H(Q)-20 * L E N G T H(P, Q) /(D E P T H(Q)-D E P T H(P))$

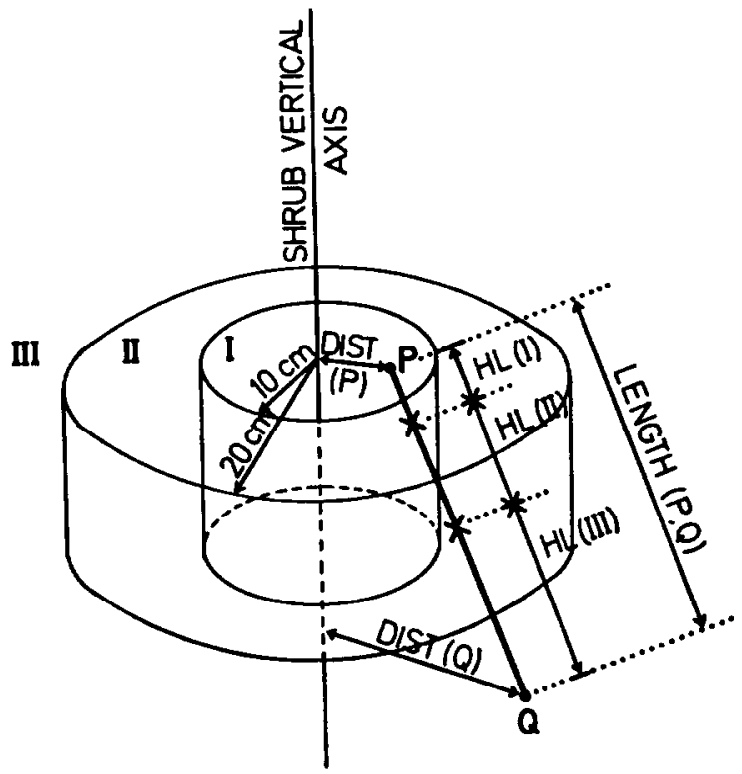

Fig. 3. Model used to estimate horizontal distribution of roots.

$P$ and $Q:$ points of a root between which it can be considered a straight segment.

Data: DIST(P), DIST $(Q)$ and LENGTH $(P, Q)$.

Unknowns: length of segment $P Q$ included in each range of distances from plant's vertical axis (HLOj)).

Solution:

$H L(I)=10-D I S T(P) * L E N G T H(P, Q) /(D I S T(Q) D I S T(P))$

$H L(I I)=20-10 * \operatorname{LENGTH}(P, Q) /(D I S T(Q)-D I S T(P))$

$H L(I I I)=D I S T(Q)-20 * \operatorname{LENGTH}(P, Q) /(D I S T(Q)-D I S T(P))$

between the 2 dimensions which could be important in the interpretation of the roots' arrangement.

Analysis of covariance was applied to the data with total root length per plant as the covariate. Function adjustment was performed by regression analysis.

\section{Results and Discussion}

The method detected differences between the 2 species: two thirds of mata mora's root length was found in the first $40 \mathrm{~cm}$ of the soil in a radius of $1.50 \mathrm{~m}$, whereas neneo shows the same proportion of its total root length in the $20-60 \mathrm{~cm}$ layer and in a circle of $1.20 \mathrm{~m}$ around the plant.

Compared with qualitative descriptions such as photographs or drawings, this method has the advantage of allowing statistical comparisons. Replication was possible since working in the $45^{\circ}$ 


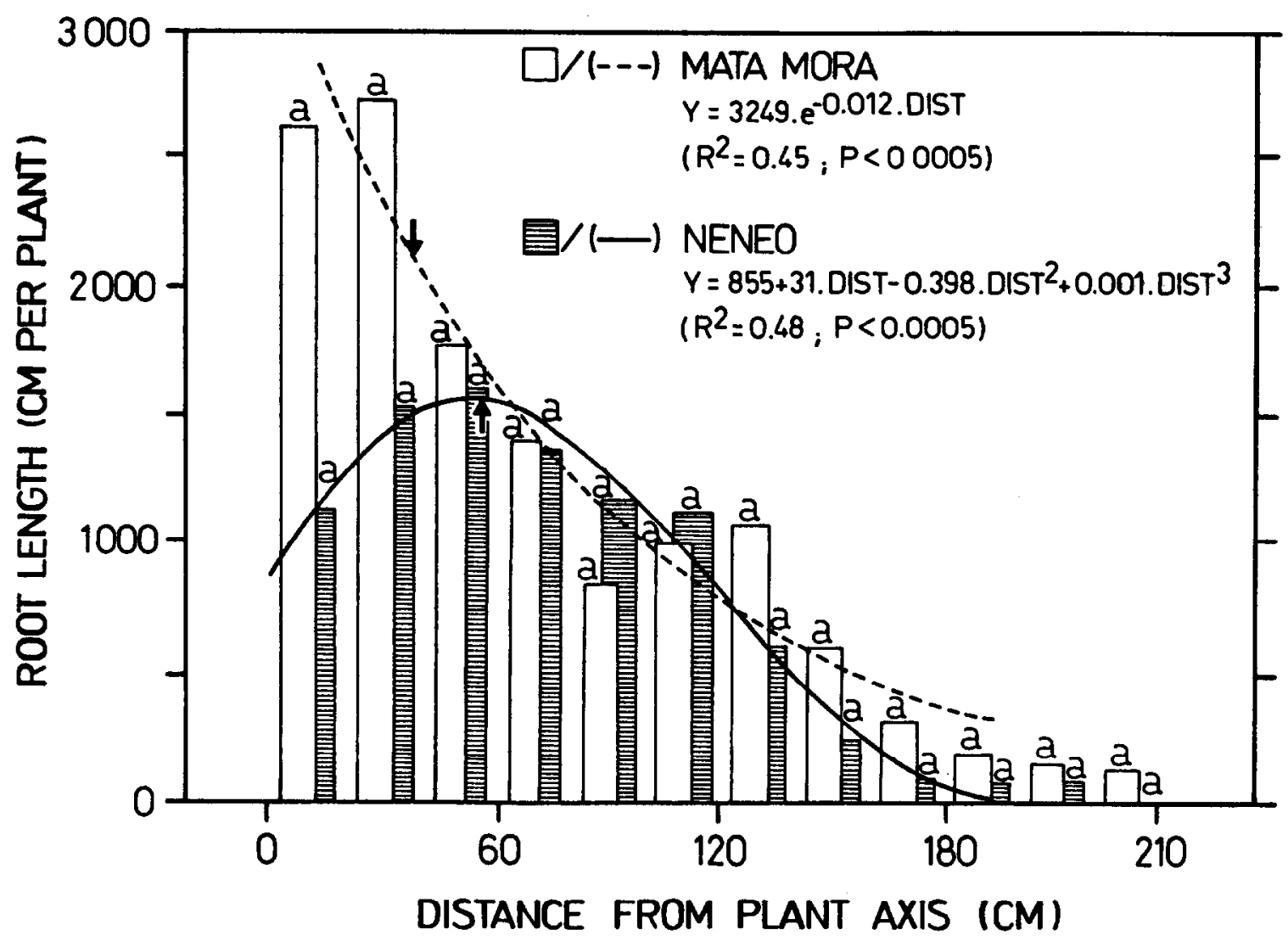

Fig. 4. Horizontal distribution of roots. Bars show average root length per plant $(\mathrm{N}=5)$ found within each $20 \mathrm{~cm}$ distance interval. Different letters at the same distance range mean significant differences $(\mathrm{P}<0.05$ ) between species through ANCOVA (using total root length per plant as independent variable). Arrows indicate the average location of canopy edge for each species.

sector reduced sampling time to about 6 hours per plant (trench digging excluded).

Maximum and average values of root density obtained here, around 100 and $1.4 \mathrm{~cm} / \mathrm{dm} 3$ respectively, are lower than those observed by other authors in species from arid environments (e.g., Kummerow et al. 1978). This underestimation derives from the difficulty in detecting roots smaller than $0.5 \mathrm{~mm}$ in diameter, which have the greatest length per unit of biomass. However, we expect root spreading not to be affected by fine roots, since they would probably lack secondary growth.

Average root length was greater in mata mora $(12,776 \mathrm{~cm} /$ plant; $\mathrm{CV}=32 \%)$ than in neneo $(8,850 \mathrm{~cm} / \mathrm{plant} ; \mathrm{CV}=55 \%)$; but the difference was not statistically significant. In both species, for each depth, root length followed a similar pattern with distance and, conversely, at each distance range the vertical pattern within a species remained unchanged. So, the analysis of root arrangement was made separately for each dimension.

The analysis of the horizontal distribution of roots revealed that the amount of roots under the projection of the shrub canopy is less than $50 \%$ of the total in both species, and that roots reach distances greater than $2 \mathrm{~m}$ (Fig. 4). Considering that woody individuals in this site average $3 \mathrm{~m}$ apart (Soriano et al., unpublished data), root spreading would be enough to allow some degree of overlapping between root systems of adjacent shrubs. Both species demonstrated a similar decrease in the amount of roots as the distance from the canopy edge increased (Fig. 4).

The vertical distribution of roots followed a different pattern in each species: whereas mata mora had most of its roots close to the soil surface, neneo showed its maximum concentration between 30 and $50 \mathrm{~cm}$ of depth (Fig. 5). The best fit was obtained with equations of a negative exponential type ( $Y=2897 . \hat{e}(0.019$.DEPTH)) and parabolic type $(Y=-363++79$.DEPTH-0.81.DEPTH2), respec- tively. Significant differences between species were found in the upper layer $(0-30 \mathrm{~cm})$ and in a lower one $(50-70 \mathrm{~cm})$ (Fig. 5 ).

The soil of this community has a calcareous layer at $40 \mathrm{~cm}$ depth (Golluscio et al. 1982, Soriano and Sala 1983). Thus, most of mata mora's roots $(73 \%)$ are between that stratum and the soil surface, and the most of neneo's were found included in the calcareous layer or near it. This would mean reduced overlapping at lower depths with grass roots for neneo than for mata mora, since grasses have a large portion of their underground biomass in the upper $30 \mathrm{~cm}$ of the soil (Soriano et al. 1987).

These data allow an interpretation of the differential responses of the 2 shrubs to grazing in the community under study. Whereas mata mora increased its importance when sheep grazing pressure was high (Soriano 1956, Busacca 1981), neneo does not show a clear variation in its cover in response to range use (Busacca 1981). Browsing is minimal in these species (Bonvisuto et al. 1983). As grass biomass decreases under the effect of grazing, it may be expected that water and nutrient consumption by grasses also decreases. In this case, a greater supply of these resources would be available in the upper centimeters of soil, where mata mora has more roots (and supposedly more root activity) than neneo. In this situation, mata mora would be able to increase its biomass per plant or its number of individuals. In addition, the overlap of roots of grasses and mata mora would also have a temporal dimension since neither of them show a dormancy period (Soriano 1983).

\section{Literature Cited}

Böhm, W. 1979. Methods of studying root systems. Springer Verlag, Berlin.

Bonvisuto, G., E. Moricz de Tecso, O. Astibia y J. Anchorena. 1983. Resultados preliminares sobre los hábitos dietarios de ovinos en un pastizal semidesértico de Patagonia. IDIA (INTA) no. 36 (suplem.): 243-253. 


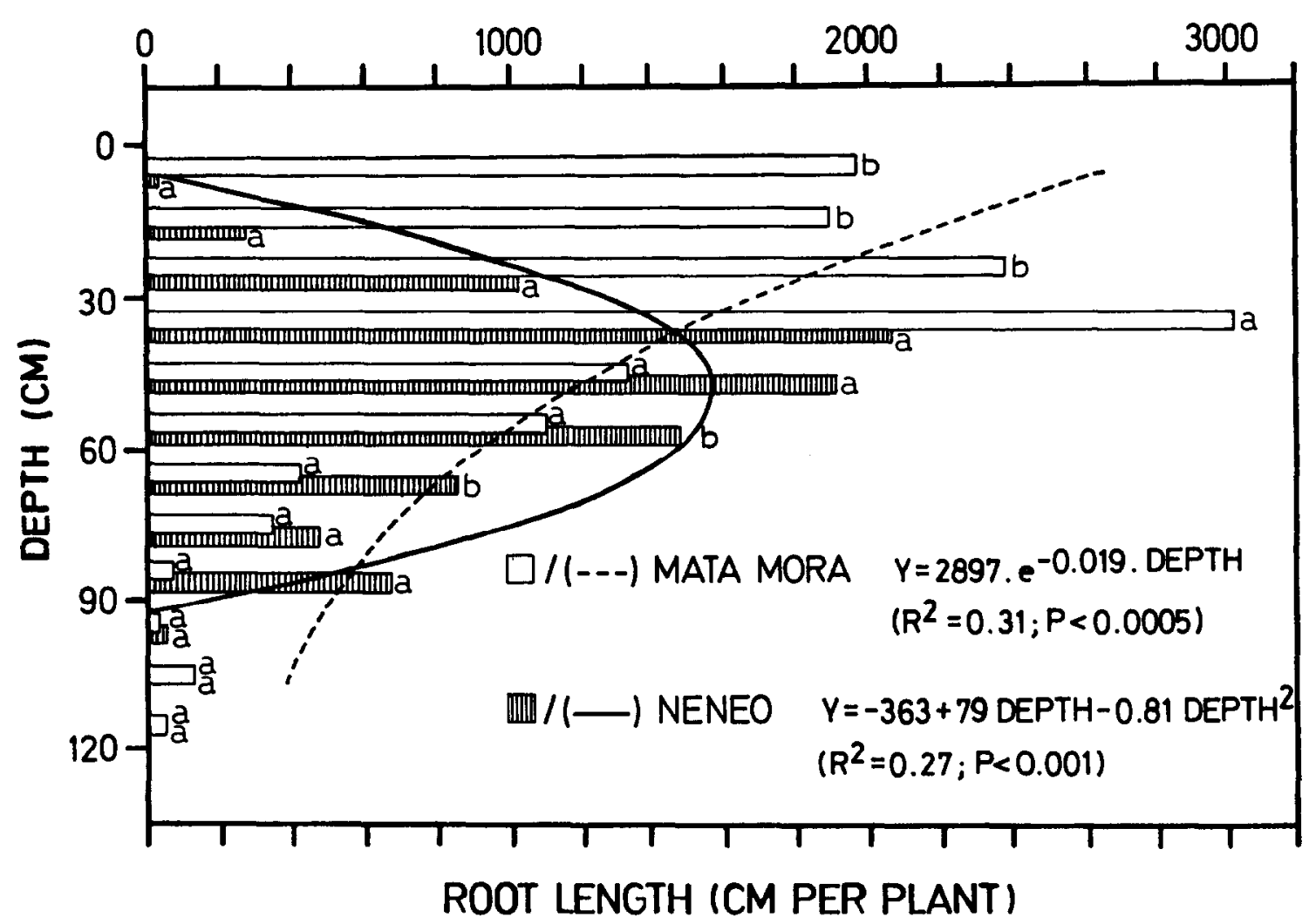

Fig. 5. Vertical distribution of roots. Bars show average root length per plant $(\mathrm{N}=5)$ found within each $10 \mathrm{~cm}$ depth interval. Different letters at the same depth mean significant differences $(R<0.05)$ between species through ANCOVA (using total root length per plant as independent variable).

Busacea, J.P. 1981. El gradiente de uso pasturil en las estepas arbustivas del sudoeste del Chubut. Agr. Eng. Diss. Univ. Buenos Aires.

Ferníndez A., R.J. 1986. Estimación de la productividad primaria neta aérea de pastos y arbustos en la estepa árida patagónica. Agr. Eng. Diss. Univ. Buenos Aires.

Golluscio, R.A., R.J.C. León y S.B. Perelman. 1982. Caracterización fitosociológica de la estepa del oeste de Chubut; su relación con el gradiente ambiental. Bol. Soc. Arg. Bot. 21:299-324.

Golluscio, R.A. y O.E. Sala. 1985. Sistemas radicales de las hierbas del pastizal de coirón amargo: una clasificación funcional. Comunicación a las 2 las Jornadas argentinas de Botánica. Salta, Argentina.

Kummerow, J., D. Krause, and W. Jow. 1978. Seasonal changes of fine root density in the southern californian chaparral. Oecologia (Berl.) 37:201-212.
Soriano, A. 1956. Aspectos ecológicos y pasturiles de la vegetación patagónica relacionados con su estado y capacidad de recuperación. Rev. Inv. Agr. (INTA) 10:349-372.

Soriano, A. 1981. Ecologia del pastizal de coirón amargo en el sudoeste de Chubut. Producción Animal (Buenos Aires, Argentina) 8:38-43.

Soriano, A. 1983. Deserts and semi-deserts of Patagonia. p. 426-460. In: N.E. West (ed.), Temperate deserts and semi-deserts. Elsevier Sci. Publ. Co., Amsterdam.

Soriano, A., R.A. Golluscio, and E. Satorre. 1987. Spatial heterogeneity of the root systems of grasses in the Patagonian arid steppe. Bull. Torrey Bot. Club. 114:103-108.

Soriano, A., and O.E. Sala. 1983. Ecological strategies in a Patagonian arid steppe. Vegetatio 56:9-15. 